\title{
Abnormal Diastolic Blood Pressure and Heart Rate Reactions to Tilting in Diabetes Mellitus
}

\author{
G. Sundkvist, B. Lilja, and L.-O. Almér \\ Departments of Medicine and Clinical Physiology, University of Lund, Malmö General Hospital, Malmö, Sweden
}

\begin{abstract}
Summary. The orthostatic reaction to tilting was studied in 46 diabetics without symptoms of autonomic neuropathy and in 31 age-matched healthy control subjects. After tilting, the diastolic blood pressure rose in the control subjects but was unchanged or tended to fall in the diabetics, except in those of short duration without retinopathy. After tilting, the control subjects showed an immediate increase in heart rate with the highest value at $8.4 \pm 1.0 \mathrm{~s}$ (mean $\pm \mathrm{SEM}$ ), followed by a transient decrease with lowest value at $21.2 \pm 0.9 \mathrm{~s}$. The acceleration and brake index measured the changes in heart rate. The brake index was lower in diabetics of short duration with retinopathy $(6.9 \pm 1.6)$ than in those without $(14.4 \pm 2.3, \mathrm{p}<0.01)$ as well as matched control subjects $(18.7 \pm 2.5, \mathrm{p}<0.01)$. In the diabetics of long duration no differences were shown between those with or without retinopathy but the acceleration $(10.3 \pm 1.6$ vs $19.9 \pm 2.3, \mathrm{p}<0.05)$ and the brake index $(5.3 \pm 1.4$ vs $19.9 \pm 2.3$, $\mathrm{p}<0.01$ ) were lower in those with vagal neuropathy.
\end{abstract}

Key words: Long term diabetes, diabetic neuropathy, diabetic retinopathy, autonomic nervous system, postural hypotension, orthostatic adaptation, heart rate, blood pressure, maximal deep breathing, orthostatic test, tilt table.

In 1945 Rundles [1] showed that postural hypotension in diabetes mellitus was a feature of general autonomic neuropathy, as later confirmed by others [2-3].

By the development of new methods it has been possible to demonstrate vagal defects in the respiratory influence on heart rate in autonomic neuropathy [4-7]. It has also been shown that the vagal nerve regulates the immediate heart rate reaction to standing up [8]. An active orthostatic test after standing up is difficult to standardise and needs close patient cooperation. A passive test on a tilt table is simpler and gives a better opportunity to measure both the immediate and late heart rate changes as well as alterations in blood pressure. The present study was designed to evaluate the reaction to tilting in diabetics without autonomic symptoms. Another aim was to correlate our previous autonomic neuropathy test, a maximal deep breathing procedure [7], to the orthostatic findings, and in addition relate these to retinopathy and the duration of diabetes.

\section{Material and Methods}

\section{Subjects}

Fifty-two insulin dependent diabetics without symptoms of autonomic neuropathy (according to a questionnaire) were studied. No patients were taking any medication apart from insulin. Twenty-six patients (age 20-46 years, mean 31) had short to moderate duration of diabetes (5-19 years, mean 11) and 13 of these had developed retinopathy (at 6-15 years of diabetes, mean 11). The other 13 had no retinopathy but were closely matched with regard to sex and age (Table 1). There were 6 female and 7 male pairs.

The remaining 26 diabetics (age 35-72 years, mean 55) had long duration of diabetes (21-49 years, mean 35) and 13 were without retinopathy. These patients were matched as regards sex and, as far as possible, age. This group also contained 6 female and 7 male pairs. For technical reasons and because of frequent extra systoles 3 male subjects and their corresponding match were excluded. Consequently, 4 male and 6 female pairs were left for the final assessment.

The control group consisted of 31 volunteers who had passed a health examination (age 28-74 years, mean 47). Fifteen were females. When comparing the results, diabetics of short duration were matched with younger controls, aged $28-48$ years, and the diabetics of long duration with those aged $40-74$ years. Thus, 14 of the controls, aged $40-48$ years, appeared in both control groups. Informed consent was obtained from all subjects.

\section{Procedures}

All diabetics had their fundi dilated and underwent ophthalmoscopy, performed by the same experienced ophthalmologist. After a vital capacity test [7] had been performed the subject was fas- 
Table 1. R-R-intervals and heart rate indices on tilting in diabetics of short duration and matched controls

\begin{tabular}{|c|c|c|c|c|c|c|c|}
\hline \multirow[t]{3}{*}{ Groups } & \multirow{3}{*}{$\begin{array}{l}\text { Age } \\
\text { (years) }\end{array}$} & \multirow{3}{*}{$\begin{array}{l}\text { Duration of } \\
\text { diabetes } \\
\text { (years) }\end{array}$} & \multicolumn{3}{|l|}{ R-R-intervals } & \multirow{3}{*}{$\begin{array}{l}\text { Acceleration } \\
\text { index }\end{array}$} & \multirow{3}{*}{$\begin{array}{l}\text { Brake } \\
\text { index }\end{array}$} \\
\hline & & & at rest & $\begin{array}{l}1 \text { min after } \\
\text { tilting }\end{array}$ & $\begin{array}{l}10 \text { min after } \\
\text { tilting }\end{array}$ & & \\
\hline & & & $\mathrm{s}$ & $\mathrm{s}$ & $\mathrm{s}$ & & \\
\hline $\begin{array}{l}\text { Controls }(28-48 \text { years }) \\
\quad(\mathrm{n}=21)\end{array}$ & $40 \pm 2$ & - & $0.90 \pm 0.03$ & $0.79 \pm 0.03^{\mathrm{i}}$ & $0.73 \pm 0.03^{k}$ & $21.0 \pm 1.3$ & $18.7 \pm 2.5$ \\
\hline \multicolumn{8}{|l|}{ Diabetics } \\
\hline $\begin{array}{l}\text { Without retinopathy } \\
(\mathrm{n}=13)\end{array}$ & $32 \pm 2^{b}$ & $10 \pm 1$ & $0.82 \pm 0.03$ & $0.62 \pm 0.02^{\mathrm{c}, \mathrm{i}}$ & $0.57 \pm 0.02^{\mathrm{b}, \mathrm{k}}$ & $22.4 \pm 1.3$ & $14.4 \pm 2.3$ \\
\hline $\begin{array}{l}\text { With retinopathy } \\
(\mathrm{n}=13)\end{array}$ & $30 \pm 2^{b}$ & $13 \pm 1^{\mathrm{d}}$ & $0.75 \pm 0.03^{c}$ & $0.61 \pm 0.02^{\mathrm{c}, \mathrm{i}}$ & $0.57 \pm 0.02^{\mathrm{b}, \mathrm{k}}$ & $16.9 \pm 2.8$ & $6.9 \pm 1.6^{\mathrm{b}, \mathrm{e}}$ \\
\hline $\begin{array}{l}\text { Normal } \mathrm{E} / \mathrm{I} \text { ratio } \\
\text { and without retinopathy } \\
(\mathrm{n}=10)\end{array}$ & $32 \pm 2^{a}$ & $11 \pm 1$ & $0.82 \pm 0.02$ & $0.61 \pm 0.02^{\mathrm{b}, \mathrm{i}}$ & $0.57 \pm 0.02^{\mathrm{b}, \mathrm{j}}$ & $23.7 \pm 1.4$ & $15.8 \pm 2.7$ \\
\hline $\begin{array}{l}\text { Abnormal E/I ratio } \\
\text { and without retinopathy } \\
(\mathrm{n}=3)\end{array}$ & $31 \pm 3$ & $8 \pm 1$ & $0.81 \pm 0.11$ & $0.64 \pm 0.08$ & $0.56 \pm 0.11$ & $17.9 \pm 1.6^{\mathrm{f}}$ & $9.9 \pm 4.3$ \\
\hline $\begin{array}{l}\text { Normal E/I ratio } \\
\text { and with retinopathy } \\
(\mathrm{n}=6)\end{array}$ & $25 \pm 2^{c}$ & $11 \pm 1$ & $0.81 \pm 0.03$ & $0.62 \pm 0.02^{\mathrm{a}, \mathrm{h}}$ & $0.59 \pm 0.02^{\mathrm{a}, \mathrm{j}}$ & $20.3 \pm 3.1$ & $10.6 \pm 1.9$ \\
\hline $\begin{array}{l}\text { Abnormal E/I ratio } \\
\text { and with retinopathy } \\
(\mathrm{n}=7)\end{array}$ & $35 \pm 2^{\mathrm{g}}$ & $14 \pm 1^{\mathrm{f}}$ & $0.71 \pm 0.03^{\mathrm{c}, \mathrm{f}}$ & $0.59 \pm 0.03^{\mathrm{b}, \mathrm{h}}$ & $0.55 \pm 0.03^{b}$ & $14.0 \pm 4.5$ & $3.6 \pm 2.0^{\mathrm{b}}$ \\
\hline
\end{tabular}

Results are given as mean \pm SEM. Statistical comparisons were made between diabetics and controls, between diabetics with and without retinopathy, and in the groups with and without retinopathy between those with abnormal $\mathrm{E} / \mathrm{I}$ ratio and those with normal $\mathrm{E} / \mathrm{I}$ ratio. In all groups the $1 \mathrm{~min} R-\mathrm{R}$-interval was compared to that at rest and $10 \mathrm{~min}$. Absence of superscript indicates no statistical difference. ${ }^{a} \mathrm{p}<0.05$ vs controls, ${ }^{b} \mathrm{p}<0.01$ vs controls, ${ }^{\mathrm{c}} \mathrm{p}<0.001$ vs controls, ${ }^{\mathrm{d}} \mathrm{p}<0.05$ vs diabetics without retinopathy, ${ }^{\mathrm{e}} \mathrm{p}<0.01$ vs diabetics without retinopathy, ${ }^{\mathrm{f}} \mathrm{p}<0.05$ vs diabetics with normal $\mathrm{E} / \mathrm{I}$ ratio, ${ }^{\mathrm{g}} \mathrm{p}<0.01$ vs diabetics with normal $\mathrm{E} / \mathrm{I}$ ratio, ${ }^{\mathrm{h}} \mathrm{p}<0.01$ vs at rest, ${ }^{\mathrm{i}} \mathrm{p}<0.001 \mathrm{vs}$ at rest, ${ }^{\mathrm{j}} \mathrm{p}<0.05$ vs $1 \mathrm{~min}$, and ${ }^{\mathrm{k}} \mathrm{p}<0.01$ vs $1 \mathrm{~min}$

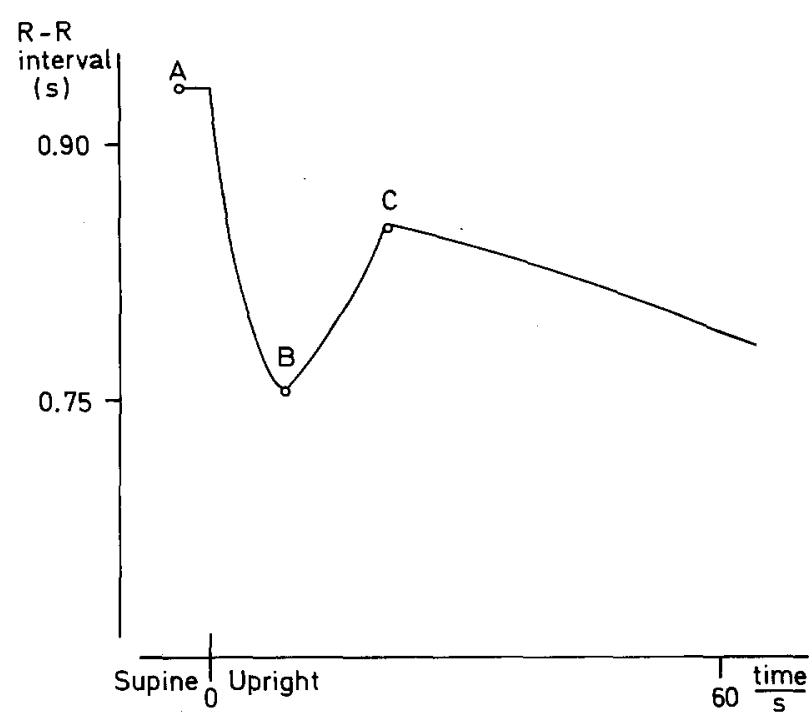

Fig 1. Schematic changes of the R-R-intervals immediately after tilting. $A=R-R$-interval at rest. $B=$ shortest $R-R$-interval after tilting. $\mathrm{C}=$ longest $\mathrm{R}-\mathrm{R}$-interval after $\mathrm{B}$

tened to a tilt table with straps around the upper parts of the chest, thighs and ankles with his feet on a bottom plate. To start with, the table was tilted head up in order to familiarise the subject with the procedure. After that the subject was returned to the supine position for $10 \mathrm{~min}$ and was then tilted to the upright position $\left(90^{\circ}\right)$ in
$2 \mathrm{~s}$ and remained so for $10 \mathrm{~min}$. Finally, a tilt back manoeuvre to the supine position was performed and the subject remained in that position for another minute. Continous electrocardiographic (ECG) recording was started $1 \mathrm{~min}$ before tilting and was finished 1 min after return to the supine position. Systolic and diastolic blood pressures were recorded indirectly in the right arm with a sphygmomanometer 4 min before tilting and then every minute.

Evaluation of Heart Rate. A normal R-R-interval curve before and during the first minute of the orthostatic test is shown in Figure 1. After tilting, there was an immediate acceleration in heart rate. Among the controls the mean shortest R-R-interval (B) was $8.4 \pm$ $1.0 \mathrm{~s}$ after tilting. The acceleration phase was followed by a transient decrease in heart rate with the lowest value (longest $\mathrm{R}-\mathrm{R}$ interval $=$ C) $21.2 \pm 0.9 \mathrm{~s}$ after tilting.

Calculations. The R-R-intervals were measured during the first $30 \mathrm{~s}$ of the last min before tilting and the mean value was taken as the R-R-interval at rest (A in Fig. 1). During the first minute after tilting the shortest R-R-interval (B) before the transient decrease was selected as well as the longest (C) after B. The mean R-Rintervals were then determined every minute. All R-R-intervals were expressed in seconds. To further clarify the initial changes, we estimated $\frac{A-B}{A} \times 100$ (acceleration index) and $\frac{C-B}{A} \times 100$ (brake index). In addition, the ratio between the 30 th $\mathrm{R}-\mathrm{R}$-interval in upright position and the 15 th was calculated (30:15 ratio) [8]. Comparisons of the R-R-intervals and blood pressures were made between rest, 1 , and $10 \mathrm{~min}$ after tilting.

Vital Capacity Test. In brief, 6 maximal expirations and inspirations were performed during $1 \mathrm{~min}$ of continous ECG-recording. 
Table 2. Blood pressure changes on tilting in diabetics of short duration and matched controls

\begin{tabular}{|c|c|c|c|c|c|c|}
\hline \multirow[t]{2}{*}{ Groups } & \multicolumn{3}{|c|}{ Systolic blood pressure (mm Hg) } & \multicolumn{3}{|c|}{ Diastolic blood pressure $(\mathrm{mm} \mathrm{Hg})$} \\
\hline & at rest & $\begin{array}{l}1 \text { min after } \\
\text { tilting }\end{array}$ & $\begin{array}{l}10 \mathrm{~min} \text { after } \\
\text { tilting }\end{array}$ & at rest & $\begin{array}{l}1 \text { min after } \\
\text { tilting }\end{array}$ & $\begin{array}{l}10 \mathrm{~min} \text { after } \\
\text { tilting }\end{array}$ \\
\hline $\begin{array}{l}\text { Controls }(28-48 \text { years }) \\
\quad(\mathrm{n}=21)\end{array}$ & $116 \pm 3$ & $114 \pm 3$ & $113 \pm 3$ & $73 \pm 2$ & $77 \pm 2^{\mathrm{e}}$ & $80 \pm 2$ \\
\hline \multicolumn{7}{|l|}{ Diabetics } \\
\hline $\begin{array}{l}\text { Without retinopathy } \\
(\mathrm{n}=13)\end{array}$ & $118 \pm 4$ & $117 \pm 6$ & $113 \pm 5$ & $76 \pm 3$ & $83 \pm 3^{e}$ & $82 \pm 4$ \\
\hline $\begin{array}{l}\text { With retinopathy } \\
(\mathrm{n}=13)\end{array}$ & $122 \pm 3$ & $121 \pm 5$ & $118 \pm 5$ & $82 \pm 3^{a}$ & $84 \pm 2$ & $85 \pm 3$ \\
\hline $\begin{array}{l}\text { Normal } E / I \text { ratio } \\
\text { and without retinopathy } \\
(n=10)\end{array}$ & $117 \pm 4$ & $114 \pm 7$ & $110 \pm 5$ & $74 \pm 3$ & $80 \pm 4^{\mathrm{d}}$ & $78 \pm 3$ \\
\hline $\begin{array}{l}\text { Abnormal E/I ratio } \\
\text { and without retinopathy } \\
(\mathrm{n}=3)\end{array}$ & $122 \pm 7$ & $125 \pm 5$ & $128 \pm 13$ & $83 \pm 7$ & $93 \pm 2^{b}$ & $100 \pm 5^{\mathrm{b}, \mathrm{c}}$ \\
\hline $\begin{array}{l}\text { Normal E/I ratio } \\
\text { and with retinopathy } \\
(\mathrm{n}=6)\end{array}$ & $116 \pm 2$ & $114 \pm 3$ & $113 \pm 2$ & $86 \pm 4^{b}$ & $86 \pm 4$ & $86 \pm 4$ \\
\hline $\begin{array}{l}\text { Abnormal E/I ratio } \\
\text { and with retinopathy } \\
(\mathrm{n}=7)\end{array}$ & $127 \pm 5^{\mathrm{a}}$ & $126 \pm 9$ & $122 \pm 8$ & $78 \pm 3$ & $81 \pm 3$ & $83 \pm 3$ \\
\hline
\end{tabular}

Results are given as mean \pm SEM. Statistical comparisons were made between diabetics and controls, between diabetics with and without retinopathy, and in groups with and without retinopathy between those with abnormal $\mathrm{E} / \mathrm{I}$ ratio and those with normal $\mathrm{E} / \mathrm{I}$ ratio. In all groups the $1 \mathrm{~min}$ value was compared to that at rest and $10 \mathrm{~min}$. Absence of superscript indicates no statistical difference. ${ }^{a} \mathrm{p}<0.05$ vs controls, ${ }^{b} \mathrm{p}<0.01$ vs controls, ${ }^{\mathrm{c}} \mathrm{p}<0.05$ vs diabetics with normal $\mathrm{E} / \mathrm{I}$ ratio, ${ }^{\mathrm{d}} \mathrm{p}<0.05$ vs at rest, and ${ }^{\mathrm{e}} \mathrm{p}<0.01$ vs at rest

The $\mathrm{E} / \mathrm{I}$ ratio was calculated from the mean values of the longest R-R-intervals during expiration (E) and the shortest during inspiration (I). A ratio less than the mean of the controls -1 SD was considered abnormal (in short duration $<1.18$ and in long duration <1.12).

Statistical Analysis. Two-tailed t-tests for unpaired and, when appropriate, paired data were used. Indices and ratios were analysed by two-tailed Mann-Whitney U-test and Wilcoxon signed rank test because of non-normal distribution. Results are given as mean \pm SEM.

\section{Results}

\section{Retinopathy and Duration}

In the diabetics of short duration, the mean R-Rinterval at rest (Fig. 2 and Table 1) was significantly shorter in those with retinopathy than in the controls. After tilting, the R-R-intervals decreased significantly between rest and $1 \mathrm{~min}$ as well as between $1 \mathrm{~min}$ and $10 \mathrm{~min}$ in the diabetics with or without retinopathy and in the controls. The mean brake index was significantly lower in the diabetics with retinopathy.

Diastolic blood pressure rose significantly during the first minute in the controls as well as in the diabetics without retinopathy, but not in those with retinopathy (Table 2 ).

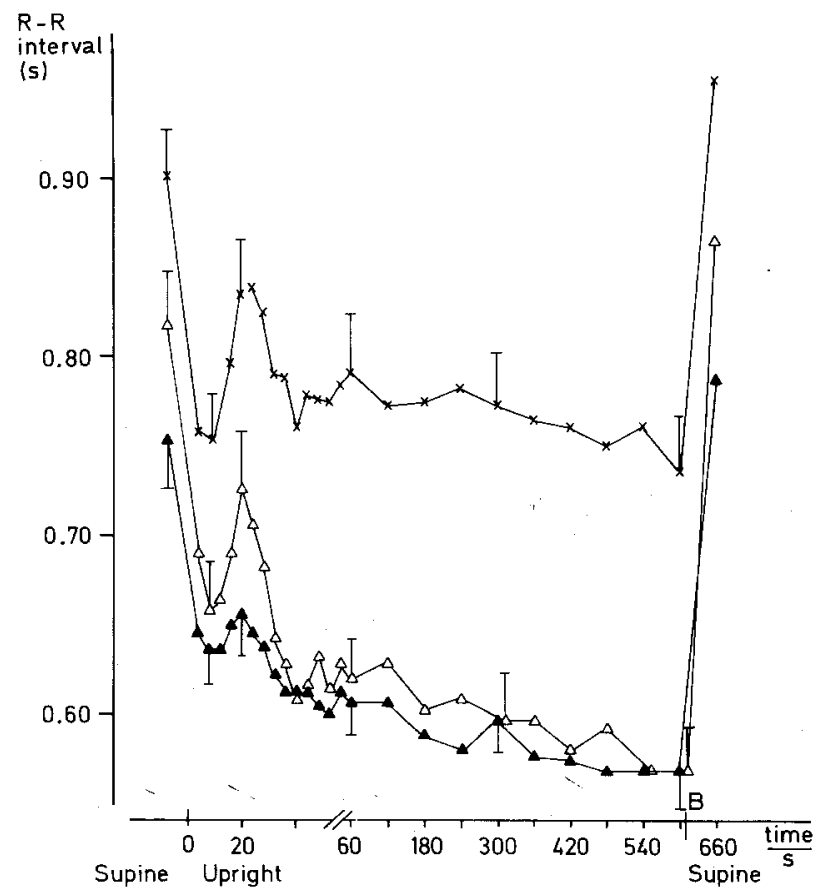

Fig 2. Heart rate changes during the orthostatic test in diabetics of short duration and matched controls. Vertical bars $=1$ SEM. $B$, subjects returned to the supine position. $x-x$, controls $(n=21)$; $\triangle-\Delta$, diabetics without retinopathy $(n=13) ; \boldsymbol{\Delta}-\boldsymbol{\Lambda}$, diabetics with retinopathy $(n=13)$ 
Table 3. R-R-intervals and heart rate indices on tilting in diabetics of long duration and matched controls

\begin{tabular}{|c|c|c|c|c|c|c|c|}
\hline \multirow[t]{3}{*}{ Groups } & \multirow{3}{*}{$\begin{array}{l}\text { Age } \\
\text { (years) }\end{array}$} & \multirow{3}{*}{$\begin{array}{l}\text { Duration } \\
\text { diabetes } \\
\text { (years) }\end{array}$} & \multicolumn{3}{|l|}{ R-R-intervals } & \multirow{3}{*}{$\begin{array}{l}\text { Acceleration } \\
\text { index }\end{array}$} & \multirow{3}{*}{$\begin{array}{l}\text { Brake } \\
\text { index }\end{array}$} \\
\hline & & & at rest & $\begin{array}{l}1 \text { min after } \\
\text { tilting }\end{array}$ & $\begin{array}{l}10 \text { min after } \\
\text { tilting }\end{array}$ & & \\
\hline & & & $\mathrm{s}$ & s & $\mathrm{s}$ & & \\
\hline $\begin{array}{l}\text { Controls }(40-74 \text { years }) \\
\quad(\mathrm{n}=24)\end{array}$ & $53 \pm 2$ & - & $0.91 \pm 0.03$ & $0.80 \pm 0.03^{\mathrm{i}}$ & $0.76 \pm 0.03^{1}$ & $17.0 \pm 1.5$ & $14.2 \pm 1.8$ \\
\hline \multicolumn{8}{|l|}{ Diabetics } \\
\hline $\begin{array}{l}\text { Without retinopathy } \\
(\mathrm{n}=10)\end{array}$ & $56 \pm 4$ & $39 \pm 2$ & $0.80 \pm 0.04^{a}$ & $0.66 \pm 0.03^{\mathrm{b}, \mathrm{i}}$ & $0.60 \pm 0.02^{\mathrm{b}, \mathrm{k}}$ & $15.4 \pm 2.7$ & $11.0 \pm 3.9$ \\
\hline $\begin{array}{l}\text { With retinopathy } \\
(\mathrm{n}=10)\end{array}$ & $49 \pm 3^{\mathrm{e}}$ & $30 \pm 2^{\mathrm{d}}$ & $0.76 \pm 0.05^{b}$ & $0.64 \pm 0.02^{\mathfrak{c}, g}$ & $0.59 \pm 0.02^{\mathrm{b}, \mathrm{j}}$ & $12.8 \pm 2.1$ & $10.7 \pm 3.0$ \\
\hline $\begin{array}{l}\text { Normal E/I ratio } \\
\text { and without retinopathy } \\
(\mathrm{n}=4)\end{array}$ & $51 \pm 7$ & $35 \pm 3$ & $0.87 \pm 0.04$ & $0.72 \pm 0.02$ & $0.62 \pm 0.02$ & $22.1 \pm 3.2$ & $19.8 \pm 7.7$ \\
\hline $\begin{array}{l}\text { Abnormal E/I ratio } \\
\text { and without retinopathy } \\
(\mathrm{n}=6)\end{array}$ & $60 \pm 5$ & $41 \pm 3$ & $0.76 \pm 0.06^{\mathrm{a}}$ & $0.62 \pm 0.05^{\mathrm{b}, \mathrm{h}}$ & $0.59 \pm 0.04^{\mathrm{b}, \mathrm{j}}$ & $11.0 \pm 2.8$ & $5.1 \pm 2.1^{b}$ \\
\hline $\begin{array}{l}\text { Normal E/I ratio } \\
\text { and with retinopathy } \\
(\mathrm{n}=4)\end{array}$ & $44 \pm 4$ & $31 \pm 4$ & $0.77 \pm 0.11$ & $0.62 \pm 0.06^{\mathbf{a}}$ & $0.56 \pm 0.03^{a}$ & $17.7 \pm 3.4$ & $19.1 \pm 3.5$ \\
\hline $\begin{array}{l}\text { Abnormal E/I ratio } \\
\text { and with retinopathy } \\
(n=6)\end{array}$ & $53 \pm 3$ & $29 \pm 2$ & $0.76 \pm 0.04^{b}$ & $0.65 \pm 0.02^{c, h}$ & $0.62 \pm 0.03^{\mathrm{a}}$ & $9.6 \pm 2.0^{\mathrm{a}}$ & $5.0 \pm 2.3^{\mathrm{b}, \mathrm{f}}$ \\
\hline
\end{tabular}

Results are given as mean \pm SEM. Statistical comparisons were made between diabetics and controls, between diabetics with and without retinopathy, and in the groups with and without retinopathy between those with abnormal E/I ratio and those with normal E/I ratio. In all groups the $1 \mathrm{~min} R-\mathrm{R}$-interval was compared to that at rest and $10 \mathrm{~min}$. Absence of superscript indicates no statistical difference. ${ }^{\mathrm{a}} \mathrm{p}<0.05$ vs controls, ${ }^{b} p<0.01$ vs controls, ${ }^{c} p<0.001$ vs controls, ${ }^{d} p<0.05$ vs diabetics without retinopathy, ${ }^{\mathfrak{c}} \mathrm{p}<0.01$ vs without retinopathy, ${ }^{\mathrm{f}} \mathrm{p}<0.05$ vs diabetics with normal E/I ratio, ${ }^{\mathrm{g}} \mathrm{p}<0.05$ vs at rest, ${ }^{\mathrm{h}} \mathrm{p}<0.01$ vs at rest, ${ }^{\mathrm{i}} \mathrm{p}<0.001$ vs at rest, ${ }^{\mathrm{j}} \mathrm{p}<0.05 \mathrm{vs} 1 \mathrm{~min},{ }^{\mathrm{k}} \mathrm{p}<0.01$ vs $1 \mathrm{~min}$, and ${ }^{1} \mathrm{p}<0.001$ vs $1 \mathrm{~min}$

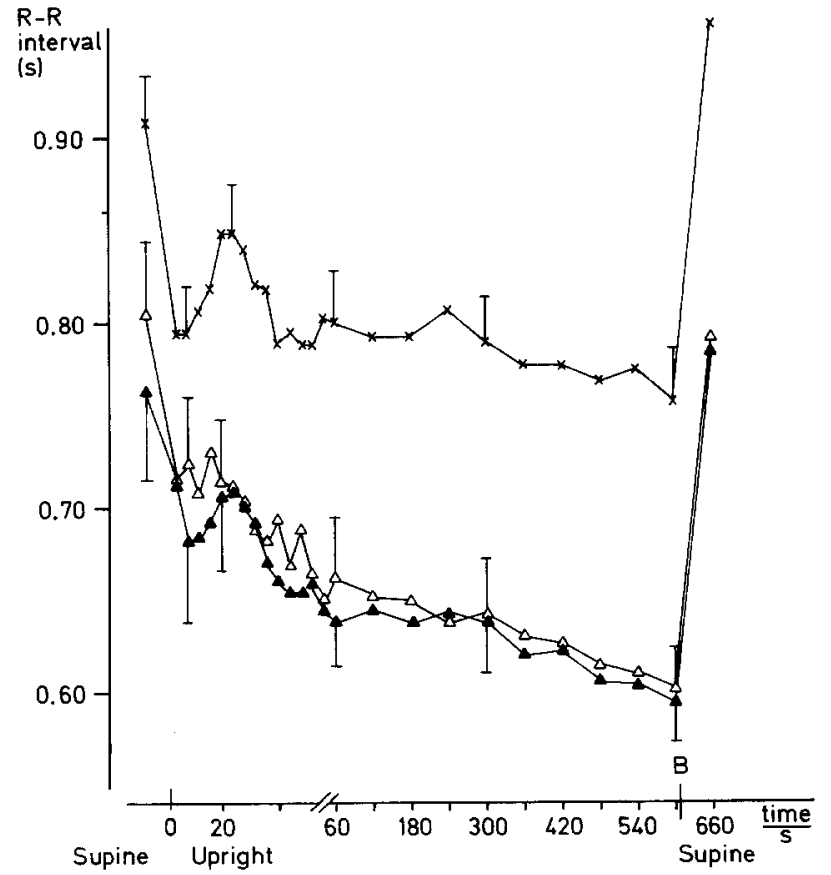

Fig 3. Heart rate changes during the orthostatic test in diabetics of long duration and matched controls. Vertical bars $=1$ SEM. $\mathrm{B}=$ subjects returned to the supine position. $x-x$, controls $(n=24)$; $\triangle-\triangle$, diabetics without retinopathy $(n=10) ; \boldsymbol{\Lambda}-\boldsymbol{\Lambda}$, diabetics with retinopathy $(\mathrm{n}=10)$
In the diabetics of long duration the mean R-Rinterval at rest (Fig. 3 and Table 3 ) was significantly shorter in those with as well as without retinopathy than in the controls. Again the R-R-intervals decreased significantly between rest and $1 \mathrm{~min}$ as well as between $1 \mathrm{~min}$ and $10 \mathrm{~min}$ in the diabetics and in the controls. The mean acceleration and brake index did not differ significantly between the diabetics and the controls. Patients with diabetes of long duration had a significantly lower mean acceleration index than those of short duration $(14.2 \pm 1.7$ vs $19.6 \pm 1.6, \mathrm{p}<0.01)$. No difference was shown in the brake index ( $10.8 \pm 2.3$ vs $10.6 \pm 1.6)$.

At rest, the mean systolic blood pressure was significantly higher in the diabetics (Table 4). The diastolic pressure rose significantly during the first minute in the controls but not in the diabetics, with or without retinopathy.

\section{Vital Capacity Test}

In the diabetics of short duration abnormal E/I ratio was shown in 7 patients with retinopathy and in 3 without. In these 10 patients the mean $\mathrm{E} / \mathrm{I}$ ratio was significantly lower in those with retinopathy (1.06 \pm 0.01 vs $1.14 \pm 0.01, p<0.05$ ). Diabetics with an abnormal ratio and retinopathy had significantly 
Table 4. Blood pressure changes on tilting in diabetics of long duration and matched controls

\begin{tabular}{|c|c|c|c|c|c|c|}
\hline \multirow[t]{2}{*}{ Groups } & \multicolumn{3}{|c|}{ Systolic blood pressure (mm Hg) } & \multicolumn{3}{|c|}{ Diastolic blood pressure (mm Hg) } \\
\hline & at rest & $\begin{array}{l}1 \text { min after } \\
\text { tilting }\end{array}$ & $\begin{array}{l}10 \mathrm{~min} \text { after } \\
\text { tilting }\end{array}$ & at rest & $\begin{array}{l}1 \text { min after } \\
\text { tilting }\end{array}$ & $\begin{array}{l}10 \mathrm{~min} \text { after } \\
\text { tilting }\end{array}$ \\
\hline $\begin{array}{l}\text { Controls }(40-74 \text { years }) \\
(\mathrm{n}=24)\end{array}$ & $122 \pm 3$ & $120 \pm 4$ & $118 \pm 3$ & $76 \pm 2$ & $82 \pm 2^{g}$ & $82 \pm 2$ \\
\hline \multicolumn{7}{|l|}{ Diabetics } \\
\hline $\begin{array}{l}\text { Without retinopathy } \\
(\mathrm{n}=10)\end{array}$ & $134 \pm 4^{\mathrm{a}}$ & $127 \pm 5$ & $120 \pm 6$ & $78 \pm 3$ & $74 \pm 3^{a}$ & $73 \pm 3^{a}$ \\
\hline $\begin{array}{l}\text { With retinopathy } \\
(\mathrm{n}=10)\end{array}$ & $140 \pm 5^{b}$ & $131 \pm 4$ & $132 \pm 5^{a}$ & $80 \pm 2$ & $79 \pm 3$ & $82 \pm 3$ \\
\hline $\begin{array}{l}\text { Normal } E / I \text { ratio } \\
\text { and without retinopathy } \\
(n=4)\end{array}$ & $129 \pm 8$ & $136 \pm 7$ & $130 \pm 9$ & $83 \pm 4$ & $83 \pm 3$ & $81 \pm 2$ \\
\hline $\begin{array}{l}\text { Abnormal } E / I \text { ratio } \\
\text { and without retinopathy } \\
(n=6)\end{array}$ & $138 \pm 5^{\mathrm{a}}$ & $119 \pm 5^{\mathrm{e}}$ & $113 \pm 8$ & $74 \pm 3$ & $68 \pm 3^{\mathrm{b}, \mathrm{d}}$ & $68 \pm 3^{\mathrm{b}, \mathrm{d}}$ \\
\hline $\begin{array}{l}\text { Normal E/I ratio } \\
\text { and with retinopathy } \\
(\mathrm{n}=4)\end{array}$ & $134 \pm 10$ & $128 \pm 7$ & $130 \pm 11$ & $80 \pm 5$ & $83 \pm 5$ & $88 \pm 3$ \\
\hline $\begin{array}{l}\text { Abnormal E/I ratio } \\
\text { and with retinopathy } \\
(n=6)\end{array}$ & $144 \pm 5^{\mathrm{b}}$ & $133 \pm 6$ & $133 \pm 6^{\mathrm{a}}$ & $79 \pm 2$ & $77 \pm 3$ & $78 \pm 4$ \\
\hline
\end{tabular}

Results are given as mean \pm SEM. Statistical comparisons were made between diabetics and controls, between diabetics with and without retinopathy, and in the groups with and without retinopathy between those with abnormal E/I ratio and those with normal E/I ratio. In all groups the $1 \mathrm{~min}$ value was compared to that at rest and $10 \mathrm{~min}$. Absence of superscript indicates no statistical difference. ${ }^{\mathrm{a}} \mathrm{p}<0.05 \mathrm{vs}$ controls, ${ }^{b} \mathrm{p}<0.01$ vs controls, ${ }^{\mathrm{c}} \mathrm{p}<0.001$ vs controls, ${ }^{\mathrm{d}} \mathrm{p}<0.01$ vs diabetics with normal $\mathrm{E} / \mathrm{I}$ ratio, ${ }^{\mathrm{e}} \mathrm{p}<0.05$ vs at rest, ${ }^{\mathrm{f}} \mathrm{p}<0.01 \mathrm{vs}$ at rest, and ${ }^{g} \mathrm{p}<0.001$ vs at rest

shorter mean R-R-interval at rest than the others with retinopathy as well as the controls (Table 1). In addition their mean brake index was significantly lower than in the controls.

In the diabetics of long duration, the prevalence of an abnormal $\mathrm{E} / \mathrm{I}$ ratio did not differ between those with or without retinopathy (Table 3 ). The number of patients was small in the different subgroups. We compared all patients of long duration with an abnormal E/I ratio to all with normal. Those with an abnormal ratio had significantly lower mean acceleration $(10.3 \pm 1.6$ vs $19.9 \pm 2.3, \mathrm{p}<0.05)$ as well as brake index $(5.3 \pm 1.4$ vs $19.5 \pm 3.9, \mathrm{p}<0.01)$.

\section{The 30:15 Ratio}

In the diabetics of short duration 10 out of $26 \mathrm{had}$ an abnormal ratio, as also found in 10 out of 21 matched controls. The prevalence in the diabetics of long duration and their matched controls was $13 / 20$ and $14 / 24$.

\section{Discussion}

The diastolic blood pressure rises normally after tilting [9]. Here a lack of rise was shown in diabetics with retinopathy. The abnormality was even present in diabetics of long duration without retinopathy. The impaired diastolic reaction points towards peripheral sympathetic lesions. This abnormality may be a simple sign of early sympathetic denervation. The diastolic abnormality was sometimes present in diabetics without vagal damage. Thus sympathetic defects may appear before parasympathetic damage.

Diabetics with vagal neuropathy have increased heart rates at rest [4]. Here this was confirmed in the diabetics with abnormal vital capacity tests.

The normal heart rate reaction during the first minute after tilting is complicated and only partly understood. The immediate increase, here estimated as the acceleration index, has been proposed to be due to withdrawal of vagal tone evoked by pressure changes at the baroreceptors of the carotid sinus and aorta [10]. This theory is supported by our finding of significantly lower values of the acceleration index in the diabetics of long duration with abnormal vital capacity tests. However, the patients of long duration had significantly lower acceleration indices than those of short duration. Thus, other mechanisms apart from neuropathy may cause low acceleration indices. Poor circulatory responses in elderly healthy subjects have been related to increased vascular stiffness with decreases in venous compliance and baroreceptor reflexes [11]. Patients with a long dura- 
tion of diabetes probably develop such changes prematurely. This is supported by our finding of significantly higher systolic blood pressures before tilting in the diabetics of long duration.

The transient decrease in heart rate during the first minute after tilting, here estimated by the brake index, might well be caused by changing vagal tone as a primary response, or possibly secondary to increased peripheral resistance induced by sympathetic counter mechanisms which peak 10-20 s after tilting [10]. If secondary this would be analogous to the decrease in heart rate after the Valsalva manoeuvre [12]. There were significantly lower brake indices in the diabetics with abnormal vital capacity tests, suggesting vagal dysfunction. In contrast to the acceleration index, no significant changes in the brake index was shown with increased duration of diabetes. Apparently, abnormalities in the brake index are specific for neuropathy. During active standing the same type of defect in brake function has been shown in diabetics with autonomic neuropathy having postural hypotension [8]. Apart from vagal neuropathy low brake indices could reflect an impaired peripheral vascular reaction secondary to the sympathetic lesions discussed above, or to plasma volume reduction. Losses of intravascular water and protein by insulin injections have been documented [13], although recently questioned [14]. As we could not find any difference in insulin dose between groups with differing blood pressure responses, this explanation seems unlikely. Sympathetic lesions are more probable. The afferent impulses from the baroreceptors and the efferent sympathetic fibres to the heart were functioning, as the heart rate increased between rest and $1 \mathrm{~min}$ even in patients with abnormal vital capacity tests.

A classical feature in diabetics with severe autonomic neuropathy is the absence of a prompt rise in heart rate after tilting or standing up [3]. The absent reaction has been suggested to be a reliable sign of autonomic neuropathy [15]. Our study shows that the impaired rise in heart rate is a late phenomenon preceded by peripheral sympathetic lesions and cardiac vagal neuropathy. This concept has support from earlier studies showing that diabetics with orthostatic symptoms often have tachycardia $[1,16,17]$. Furthermore, none of our patients developed orthostatic symptoms, not even those with significant systolic pressure reductions. In active standing it has been shown that the $30: 15$ ratio is another reliable sign of autonomic neuropathy [8]. Evidently this is not true after tilting.

Although the vital capacity test is easier to perform, the orthostatic indices are more reliable when patient cooperation is doubtful. The orthostatic test gives, by the recording of the diastolic pressure, an opportunity to register sympathetic damage in addition to parasympathetic. The procedure is innocuous and suitable in prognostic studies of autonomic neuropathy as well as in clinical work.

Acknowledgements. This study was supported by grants from Torsten and Elsa Segerfalk Foundation, the Swedish Diabetes Association, and the Swedish Medical Research Council (B77-19X499301 and B78-19X-4993-2).

\section{References}

1. Rundles RW (1945) General review with report of 125 cases. Medicine (Baltimore) 24: 111-160

2. Hosking DJ, Bennett T, Hampton JR (1978) Diabetic autonomic neuropathy. Diabetes 27: 1043-1055

3. Clarke BF, Ewing DJ, Campbell IW (1979) Diabetic autonomic neuropathy. Diabetologia 17: 195-212

4. Wheeler T, Watkins PJ (1972) Cardiac denervation in diabetes. Br Med J IV: 584-586

5. Murray A. Ewing DJ, Campbell IW, Neilson JMM, Clarke BF (1975) RR interval variations in young male diabetics. $\mathrm{Br}$ Heart J 37: 882-885

6. Gundersen HJG, Neubauer B (1977) A long-term diabetic autonomic nervous abnormality. Reduced variations in resting heart rate measured by a simple and sensitive method. Diabetologia 13: 137-140

7. Sundkvist G, Almér LO, Lilja B (1979) Respiratory influence on heart rate in diabetes mellitus. Br Med J I: 924-925

8. Ewing DJ, Campbell IW, Murray A, Neilson JMM, Clarke BF (1978) Immediate heart-rate response to standing: simple test for autonomic neuropathy in diabetes. Br Med J I: 145-147

9. Tuckman J, Shillingford J (1966) Effect of different degrees of tilt on cardiac output, heart rate, and blood pressure in normal man. Br Heart J 28: 32-39

10. Korner PI (1971) Integrative neural cardiovascular control. Physiol Rev 51: 312-367

11. Kalbfleish JH, Reinke JA, Porth CJ, Ebert TJ, Smith JJ (1977) Effect of age on circulatory response to postural and Valsalva tests. Proc Soc Exp Biol Med 156: 100-103

12. Johnson RH, Spalding JMK (1974) Disorders of the autonomic nervous system. Blackwell Scientific Publications, Oxford London Edinburgh Melbourne

13. Gundersen HJG, Christensen NJ (1977) Intravenous insulin causing loss of intravascular water and albumin and increased adrenergic nervous activity in diabetics. Diabetes 26: 551-557

14. Parving HH, Noer I, Deckert T, Lassen NA (1979) Intravenous insulin has no effect on transcapillary escape rate of albumin and on plasma volume in short-term juvenile diabetics. Diabetes 28: 282-286

15. Page M McB, Watkins PJ (1977) The heart in diabetes: autonomic neuropathy and cardiomyopathy. Clin Endocrinol Metab 6: 377-388

16. Bennett T, Hosking DJ, Hampton JR (1975) Cardiovascular control in diabetes mellitus. Br Med J II: 585-587

17. Lloyd-Mostyn RH, Watkins PJ (1975) Defective innervation of heart in diabetic autonomic neuropathy. $\mathrm{Br}$ Med J III: 15-17

Received: January 28, 1980,

and in revised form: July 8, 1980

Göran Sundkvist, M.D.

Department of Medicine

University of Lund

Malmö General Hospital

S-214 01 Malmö

Sweden 